\title{
Employment Skill Development in South Asian Countries: A renaissance of English Language.
}

\author{
Deepti Sethi ${ }^{\mathrm{a}, *}$, Shruti Agarwal ${ }^{\mathrm{b}}$ \\ ${ }^{a}$ NRI institute of Information science and Technology, Bhopal, India \\ ${ }^{b}$ Barkatullah University, Bhopal, India
}

\begin{abstract}
English has a strong demand across society" the reason being its apparent economic and social value. Several policies, initiatives and interventions are taken to promote English language learning programs as part of skills development. In South Asia skills development and English language teaching are in high demand, but the problem is how to meet these demands. In this paper we explore English language as part of skills development and what is the worth in investing our time and energy. We will explore the relationship that exists between education, English language skills, skills development and employment (economic development).

South Asia has diverse linguistic backgrounds and hence English acts as a major link language for the people. As a result of Globalization and the subsequent rise in the demand of English, nearly all South Asian countries are introducing English at the early school level. This broadens the spectrum of investigating into the national policies regarding English and examining the categorization of English language in reference to pedagogy in the countries of the South Asian region.
\end{abstract}

\section{English as an Asian Language}

The concept of English as an Asian language is based on the fact that English is here to stay as an irreplaceable language for communication and/or internation. In Southeast Asia, for example, English is used as an irrefutable lingua franca for regional cooperation in the ASEAN (Association of Southeast Asian Nations) organization comprising ten states.

The extraordinary importance of English is recognized by all the countries as a language of wider communication in Asia and of course the world around. This gives a redoubled emphasis on English language teaching (ELT). China, a country of 1.2 billion people, has 300 million students enrolled in the English classrooms. Japan is one of the countries who has initiated an action program to opened the way for improved ELT in five years, with a focus on teaching English in English in primary and secondary schools.

If we talk about India in specific the introduction of English in India was done by The British East India Company, founded in 1599, in the exclusive domains of power-government, administration, judiciary, military, education, commerce, and the media - between the 18th and the 19th centuries. As such, it was an elite social class marker facilitating upward social mobility in urban, professional circles in South Asia.English continues to enjoy this dominant status in South Asia despite resistance to it in the precolonial India (Gandhi, 1942, p. 62, 1980, p. 46), postcolonial Pakistan (Abdullah,1976), Sri Lanka (Raheem \& Ratwatte, 2004, pp. 94 6), and Bangladesh (Hossain \& Tollefson,2007, p. 248). These resistance movements were counteracted by the expansion of English through improved means of communication, especially in the electronic media and cyberspace (Crystal, 2004, pp. 64-91), and the aspiration of the expanding middle class for upward mobility both nationally and internationally.

\section{Technical and Vocational Education and Training (TVET)}

There have been efforts across South Asia to expand and improve the quality of post-school vocational education, also known as TVET (Technical and Vocational Education and Training). TVET has been defined as: the study of technologies and related sciences and the acquisition of practical skills, attitudes, understanding and knowledge relating to occupation in various sectors of economic life (UNESCO, 2013).

The approach is committed to develop a strategy of increasing skills development opportunities and making the TVET system accessible and industry-oriented. In India, too, efforts are being made to encourage school leavers to enter TVET by attempting to build correspondence between education and work.

III. The role of English in South Asia and TVET

English has continually had a presence in the Indian subcontinent due to British colonial history in the region and the language's subsequent emergence as a global force with a high instrumental value in various domains, particularly commerce and education (McArthur, 2002). As the region is linguistically diverse, English 
serves as an instrumental link language between countries and regions. It has official status in India and Pakistan. In Bangladesh, the national language is Bangla, but English has been used as a language of education and in higher law courts since colonial times. In Sri Lanka, English has been brought back as a link language after a postcolonial 'Sinhala Only' policy (Kennett, 2010). While Nepal was never part of British India, the status of English there is similar: It is classed as the country's primary foreign language and it is used as the language of higher education, particularly in STEM subjects. While English has no official status in Afghanistan, the language plays an important role as a language of development. In Iran, English is taught as a foreign language from Grade 7. Across the region,

English is considered as a parameter for accessing the best higher education opportunities, which then ultimately bring about the best employment opportunities.

While English was traditionally a prerequisite for specialised education and high-level careers, it is now rising in demand in almost all the fields. More and more employers are using English, as recruitment criteria, particularly in the private sector and in public institutions.

Communication skills in English are framed as a 'basic skill', along with computer literacy. This can be seen in the following quote from a major recruitment consultant in India: India's language diversity means that English is like Windows; an operating system. This has always been true for high end services but now applies to even many unorganised services (security, door to door sales, electricians, etc) and manufacturing because of the increased use of distributed IT systems for internal processes (Teamlease, 2012). English is also increasingly instrumental as the

language of migration: Capstick (2011) shows how fluency leads to increased opportunities for migration among migrants from Pakistan. Research from Bangladesh suggests that if migrant workers were trained in vocational skills, including English, the remittance earnings could go up by $\$ 30$ billion a year (Haque, 2010).

As English has been upheld as a mark of education, culture and status across South Asia, knowledge of the language is perceived to lead to enhanced social status (Gupta, 2001). Research on attitudes towards English often reflect a strong belief in the power of English and a desire to be one of the many who speak the languages, for reasons of practicality and prestige (see Erling et al, 2012). With the increase in the affinity for English across South Asia, English education has become more important in the national curricula as well as job requisite of these countries. In Bangladesh, for example, it is compulsory from Grade 1 and a mandatory part of a school-leaving certificate (Banu and Sussex, 2001; Mc Arthur, 2002: 328). Low cost private English-medium schools are mushrooming across the region in response to parental demand for English and as a reaction to the low quality of government school (Baird, 2009). In Andhra Pradesh, India, for example, the uptake of private schooling increased from 24 per cent among children born in 1994-5 to 44 per cent among children born in 2001-2 (Woodhead, Frost and James, 2012). Private English language tutoring schools are also common across the region (see Hamid, Sussex \& Khan, 2009). Despite these increasing efforts in English teaching and training, the low quality of education provided results in the increase of demands as it's not being met.

\section{The relationship between English and economic development}

Till now, there is only minimal hard evidence to measure the relationship between English language skills and economic for national and individual benefit. The reason being the lack of data and deficiency of proving causality. However, the picture is getting richer as increasingly nuanced econometric studies are being undertaken with ever richer data pools in response to a demand for evidence-based policy. In this section, the most recent studies conducted in this area are discussed. The report focuses strictly on quantitative studies and their findings, primarily studies which have been published since 2006. It includes a discussion of:

1. exploring the relationship between education and economic development (with a focus on South Asia).

2. trying to prove that there exists a relationship between TVET and economic development.

3. providing that the relationship between English language skills and economic development is evident(with a focus on studies concerning South Asia).

Before going into the evidence, it should be noted that focusing on the returns to education and putting the focus on economic gain exhibits a rather narrow conception of development. Broader conceptions of "human development' embrace improved governance, security, better health, the eradication of poverty, social cohesion and environmental sustainability, amongst other things. In line with this perspective, quality education:

- is important in a rights-based perspective and due to its social benefits such as reductions in fertility and mortality, empowerment, better democratic participation, etc. (Fasih et al, 2012:8). 
- $\quad \ddot{Y}$ benefits other people in society (through securing of basic cognitive skills, literacy and numeracy which bring changes that are beneficial to families and communities) (Colclough, Kingdon and Patrinos, 2010).

These factors alone justify an investment in education.

\subsection{Education and economic development}

Robust links between quality education and economic growth have been established in developing countries using a variety of econometric methods (Fasih et al, 2012; Hanushek and Woessmann, 2008; Little and Green, 2009). Some of these studies have been conducted at the national level, looking at developing countries' economic growth, while others focus more on the level of individual gains. The findings established so far are summed up by a systematic review sponsored by UKAid in 2012 which summarises the evidence on the relationship between education, skills and economic growth in low-income countries 7 (LICs). The results indicate that 8 largely human capital does have a positive and genuine effect on growth in LICs. The estimates of the effect of education and skills on economic growth give an increase varying between $0.4 \%$ and $24 \%$ per unit of education or skills investment (Hawkes and Ugur, 2012: 4).

They thus conclude with confidence that higher levels of education and skills (however they are measured) are conducive to higher productivity and the latter is conducive to higher output in the economy (Hawkes and Ugur, 2012: 10). In Figure 1 (see next page), Hawkes and Ugur demonstrate the channels through which education and skills may affect economic growth, which include productivity being improved through enhanced quality and an increase in people who join the labour market. There are also less direct channels through which education affects development, such as the fact that people who are more highly skilled can make better uses of investment and also have a higher demand for variety, leading to innovation. It is important to note that Hawkes and Ugur refer to 'human capital' having an impact on economic growth, not education per se. What contributes to development is not simply the provision of schools, teachers and materials for learners, but effective, quality education (Hanushek and Woessmann, 2008).

Education initiatives promoted through the Millennium Development Goals (MDGs) have resulted in a tremendous increase in the number of children being in school in developing countries, including South Asia. There is growing evidence, however, that in some of these contexts children are managing to formally complete their primary education without gaining the

benefits - cognitive and otherwise - that promote development (cf. Uwezo, 2012; Williams, 2013 and the ASER reports discussed below).

Finally, it should be noted that a survey of the literature on the links between education and economic growth in East Asian countries has shown that investment in education on its own is not sufficient for economic development in developing countries (Permani, 2009). Other measures need to be pursued alongside investment in education, and these

include:

- $\quad$ promoting foreign direct investment and foreign technology,

- maintaining macroeconomic stability,

- developing effective regulation,

- $\quad$ adopting a transparent financial system, and

- developing effective and respectful governance

Permani (2009) also found that the higher the level of economic development in a country, the greater the demand is for better and higher education systems.

\section{Conclusion}

These studies suggest the provision of quality education has a positive effect on economic growth

- While education is one factor that can lead individuals and nations to strengthen their opportunities for economic gain, a policy focus on education alone is not likely to bring on the desired impact.

- Education programmes need to be embedded in an overall development agenda, which also supports stability, regulation, transparency and good governance in order for there to be a significant impact

We can also sum up:

- There are several initiatives to expand the quantity and quality of skills development in South Asia, including programmes that promote English for employability.

- These programmes have arisen due to demands from employers for better skilled employees, and employees with skills in English. 
- There are also strong demands for English across society because of its perceived economic and social value.

- While skills development issues and English language teaching are in high demand, there are issues about how this demand can be met.

It is within this context that the need to understand the cost and value of providing English language teaching has arisen. If decisions are taken to invest in English language education as part of skills development, it should be recognised that providing quality English language teaching at scale requires a major investment over time. Is the investment worth

it? To help answer that question, the following section of the report introduces the academic body of literature that explores the relationship between economic development and education, skills and English language ability in South Asia. This discussion provides further insight into whether and how the provision of English language teaching might have a positive effect on an individual's and nation's development.

\section{Bibliography}

[1]. Agnihotri, R. K., \& Khanna, A. L. (Eds.). (1995). English language teaching in India: Issues and innovations. New Delhi, India: Sage.

[2]. Agnihotri, R. K., \& Khanna, A. L. (1997). Problematizing English in India. New Delhi, India: Sage.

[3]. Alam, F. (2006). Introduction to Dictionary of literary biography: South Asian writers in English.

[4]. Detroit, MI: Thomson Gale.

[5]. Bourdieu, P. (1991). Language and symbolic power (G. Raymond \& M. Adamson, Trans.). Oxford, England: Polity.

[6]. Subaltern studies IV (pp. 276-329). Delhi, India: Oxford University Press.

[7]. Crystal, D. (2004). The language revolution. Cambridge, England: Polity.

[8]. De Silva, K. M. (1996). Coming full circle: The politics of language in Sri Lanka, 1943-1996.

[9]. Ethnic Studies, XIV(1), 11-48.

[10]. Funahashi, Yoichi. 2000. Aete eigo kouyougo ron. Tokyo:Bunshun Shinsho.

[11]. Honna, Nobuyuki and Yuko Takeshita. 1998. “On Japan's Propensity for Native Speaker English: A Change in Sight." Asian Englishes Vol. 1, No. 1.

[12]. Honna, Nobuyuki, Hiroko Tina Tajima, and Kunihiko Minamoto. 2000. "Japan." In Ho Wah Kam and Ruth Y L Wong (eds.), Language Policies and Language Education: The Impact in East Asian Countries in the Next Decade. Singapore: Times Academic Press.

[13]. Honna, Nobuyuki and Yuko Takeshita. 2000. "English Language Teaching for International Understanding in Japan." EA Journal Vol. 18, No. 1

[14]. Honnna, Nobuyuki and Yuko Takeshita. 2002. "English Education in Japan Today; The Impact of Changing Policies." In Ho Wah Kam and Ruth Y L Wong (eds.), English Language Teaching in East Asia Today. Singapore: Times Media Academic Press.

[15]. Institute for International Business Communication. http://www.toeic.or.jp/toeic/OTHERS/index.html

[16]. Hall, J. K., \& Eggington, W. G. (Eds.). (2000). The sociopolitics of English language teaching. Clevedon,

[17]. England: Multilingual Matters.

[18]. Hossain, T., \& Tollefson, J. W. (2007). Language policy in education in Bangladesh. In A. B. M. Tsui \& J. W. Tollefson (Eds.), Language policy, culture, and identity in Asian contexts (pp. 241-57). Mahwah, NJ: Erlbaum.

[19]. Perera, M. (2008). Merging of context and methodology: The TESOL curriculum in Sri Lanka: A pioneering effort. In P. Dheram (Ed.), Negotiating empowerment: Studies in English language education (pp. 184-93). Delhi, India: Orient Longman.

[20]. Raheem, R., \& Ratwatte, H. (2004). Invisible strategies, visible results: Investigating language policy in Sri Lanka. In S. Mansoor, S. Meraj, \& A. Tahir (Eds.), Language policy planning and practice: A South Asian perspective (pp. 91-105). Karachi, Pakistan: Aga Khan University and Oxford University Press.

[21]. Rahman, A. (2008). Towards a culturally friendly approach to ESL teacher development in Bangladesh. In P. Dheram (Ed.), Negotiating empowerment: Studies in English language education (pp. 194-208). Delhi, India: Orient Longman.

[22]. Rahman, T. (1990). Pakistani English: The linguistic description of a non-native variety of English.

[23]. Islamabad: National Institute of Pakistan Studies, Quaid-i-Azam University.

[24]. Rahman, T. (1991). A history of Pakistani literature in English. Lahore, Pakistan: Vanguard.

[25]. Rahman, T. (1996). Language and politics in Pakistan. Delhi, India: Orient Longman.

[26]. Rahman, T. (2002). Language, ideology and power: Language-learning among the Muslims of Pakistan and North India. Karachi, Pakistan: Oxford University Press. 